Dr. B. K. Gazey and D. R. Noaks (electronic and electrical engineering); Dr. P. J. C. Lamont (pure mathematies); Dr. M. P. Osborne (zoology and comparative physiology); Dr. C. N. Roid (physical metallurgy); J. Tarney (geology); T. H. Y. Tebbutt (civil engineering). Research Fellowships, B. C. Cole (virology and bacteriology); W. A. Kelly (Sonior Research Fellow in the Department of Anatomy); Dr. T. C. Anand Kumar, S. Salmons, Dr. L. E. W. Vollrath and P. G. Wall (anatomy), W. E. M. Pryse-Phillips (Cullip Senior Research Fellow in the Department of Psychiatry).

London

Dr. C. A. B. Sмгтн, reader in genetical statisties at University College, has been appointed to the Weldon chair of biometry tenable at that College. Dr. R. K. S. Wood, reader in plant pathology at the Imperial College of Science and 'lechnology, has been appointed to the chair of plant pathology tenable at that College. Dr. P. H. Gulliver, lecturer at the School of Oriental and African Studies, has beon appointed to the readership in African anthropology tonable at that School. The title of professor of goography has been conferred on Dr. J. C. P'ugh, in respect of his post at King's College. The title of reader in mathematical statistics has been conferred on Dr. G. M. Jenkins, in respect of his post at the Imperial College of Science and Technology.

\section{New Chair in Environmental Design and Engineering, University College, London}

A NEw chair, to bo known as the Haden-l'ilkington Chair of Environmontal Design and Engineering, is to bo established in the Bartlett School of Architecture at University College, London. This has been made possible by financial support from Messrs. G. N. Haden and Sons and Messrs. Pilkington Bros., Ltd. The task of the new professor will be to investigate what makes a building pleasant, comfortable and stimulating to live and work in. Ho will instruct future architects, engineors and scientists in ways of designing a bettor environment for human beings in buildings and eities. He will be concorned with lighting, heating, ventilation and the problems of noise--with the impact of the onvironment on poople via their eyes, ears and skin. Further information can bo obtained from the Bartlett School of Architecture, University College, Gower Street, London, W.C.1.

\section{Advanced Course in Surface Chemistry and Colloids}

A ONE-YEAR postgraduate course in surfaco chemistry and colloids, leading to the degroe of M.Se., will bo held in the Department of Physical Chemistry, University of Bristol, commencing in October 1964. The courso is dosigned to give graduates an understanding of the fundamentals of surface phenomena and the opportunity of gaining experience of a wide range of exporimental techniques in surface and colloid chemistry, including electron microscopy, ultracentrifugation, $\mathrm{X}$-ray and radiochemical tochniquos, particle counting, adsorption and surface area determination, and in rheology. Further information can be obtained from the Registrar, Sonate House, Bristol 2.

\section{Lady Tata Memorial Fund Awards}

The Trustees of tho Lady Tata Memorial Fund for research in leukemia and allied disorders have made the following awards for the academic year 1964-65: Fellowship, Dr. J. de Maeyer (University of Louvain). Scholarships, Dr. G. Corneo (Laboratory of Molecular Biopathology, Milan); Dr. D. Quaglino (Institute of Medical Pathology, Modena); Dr. G. Tridente (Division of Experimental Cancor, Bari). Expenses Grants, Dr. A. Agostoni (Medical Clinic, Milan); Dr. K. M. Laurence (Welsh National School of Medicine, Penarth); Dr. B. Pedersen (University Instituto of Genetics, Copenhagon).

\section{Announcements}

Prof. P. L. Pratt, professor of crystal physics in the Department of Metallurgy, Imperial Colloge of Science and Technology, has boen awarded a gold medal and a prize of 100 guinoas by the administrators of the Sir George Beilby Memorial Fund, for his work on crystal physics with special reference to the study of plastic deformation in metallic and non-metallic erystals and the relation between defect structures and fracture behaviour. The administrators of the Fund represent the Royal Institute of Chemistry, the Society of Chemical Industry and the Institute of Motals.

Frrends of the late Dr. E. W. R. Steacie, president of the National Research Council during 1952-62 (Nature. $196,110 ; 1962)$, have established a memorial fund from the income of which a prize will be given (not necessarily annually). The E. W. R. Steacio Prize will be awarded for an outstanding contribution to the natural sciences in Canada. The first award will be mado late in 1964 and, at that time, the approximate value of the Prize will be 1,000 dollars. Furthor information can bo obtained from tho Secretary, E. W. R. Steacie Memorial Fund, 100 Sussex Drive, Ottawa.

AN international summer school on "Activation Analysis" will be hold as a NATO Advanced Study Institute at the University of Glasgow and the Scottish Research Reactor Centre during August 13-26. Further information can be obtained from Dr. J. M. A. Lenihan, 9-13 West Graham Street, Glasgow, C.4.

AN international summer institute of "Molecular Biophysics", sponsored jointly by NATO and the U.S. Office of Naval Research, will bo held at Squaw Valloy, California, during August 17-28. Further information can bo obtained from Prof. B. Pullman, Institut de Biologio Physico-Chimique, 13 rue Pierre Curie, Paris 5.

THE tenth international symposium on "Combustion" will be held in the University of Cambridge during August 17-21. The programme will include discussions on: aerodynamics in combustion; elementary combustion reactions; electrical proporties of flames. Further information can be obtained from Dr. W. G. Parker, the Combustion Institute (British Section), College of Advanced Technology, Birmingham 4.

A symposium on "Current Research in Loukæmia" will be held in the University of Cambridge during August 18-21. Lectures will be given on the following topies: cytology and cytochemistry; electron microscopy; cyto$\mathrm{g}$ netic work; in vitro studies; retiology and pathogenesis; biochemistry; immunological studies; therapy; epidemiology. Further information can be obtained from the Secretary, the Medical School, Tennis Court Road, Cambridge.

An international congress on "Logic, Methodology and l'hilosophy of Science" will be held, under the auspices of the International Union for History and Philosophy of Science, at the Hebrew University, Jerusalem, during August 26-September 2. A colloquium on "Algebraic Linguistics and Automata Theory" will be held a few days before the congress. Further information can be obtained from Prof. Y. Bar-Hillel, Hebrew University, Jerusalem.

A JoINT meeting of the Challonger Society and repre. sentatives from the Marine Laboratories (Development Commissioners' Scheme) will be held at the Marine Science Laboratories, Menai Bridge, Anglesey, during July 2 ;3. The programme will include sessions on marine biology, hydrographic and chemical studies of the Menai Straits and associated waters, and chemical factors in settlement. In addition, there will bo a discussion meeting on chemical oceanography, and demonstrations of the work of the Laboratories will also be on view. Further information can be obtained from $H$. O. Bull, The Dove Marine Laboratory, Cullercoats, Northumberland. 